\title{
MEDICINALLY IMPORTANT PLANT CLEOME GYNANDRA: A PHYTOCHEMICAL AND PHARMACOLOGICAL EXPLANATION
}

\author{
PARTHA PRADIP ADHIKARI ${ }^{1,2 *}$, SATYA BHUSAN PAUL ${ }^{2}$ \\ ${ }^{1}$ Genoine Research Laboratory Pvt. Ltd., Subhash Nagar, Karimganj - 788710, Assam, India. ${ }^{2}$ Department of Chemistry, Assam University, \\ Silchar - 788 011, Assam, India. Email: dr.parthaadhikari@gmail.com
}

Received: 16 August 2017, Revised and Accepted: 21 October 2017

\begin{abstract}
Cleome genus includes 601 plant species from the family Cleomaceae. Of more than 600 plants, 206 (34.3\%) plants are having accepted species names. Cleome gynandra Linn. is a well-known medicinal plant with traditional and pharmacological importance. A good number of secondary plant metabolites have also been isolated from different parts of $C$. gynandra. Our investigation confirms two mutant varieties of $C$. gynandra exists in India. Accordingly, the objective of this study was designed to critically evaluate the pharmacological and phytochemical evaluation of $C$. gynandra of two mutant variety, to provide a consolidated platform for research potential of both the mutant varieties of $C$. gynandra. Careful scrutiny reveals that the plant possesses a huge range pharmacological applications, such as anti-inflammatory, free radical scavenging, anticancerous, immunomodulator, and antidiabetic agents. To arrive its pharmacological importance the published papers also shown an enormous amount of phytochemicals endorsement. Scientific perusal reveals different parts of the plant has an immense medicinal importance which proofs its traditional use round the glove. But in North-Eastern region of India, the same plant abundantly found in pink mutant variety. To date, there is not much research investigation for this mutant variety to validate its pharmacological importance. Therefore, research needs to scrutinize and compare the medicinal claims of the pink mutant variety in the bio-diverse region of North-East India.
\end{abstract}

Keywords: Cleomaceae, Cleome gynandra Linn., Pharmacological, Phytochemicals, Pink mutant variety.

(C) 2018 The Authors. Published by Innovare Academic Sciences Pvt Ltd. This is an open access article under the CC BY license (http://creativecommons. org/licenses/by/4. 0/) DOI: http://dx.doi.org/10.22159/ajpcr.2018.v11i1.22037

\section{INTRODUCTION}

India is rich in its natural assets and considered as one of the 17 megadiverse nations of the world. The Indo-Burma, Western Ghats, and Eastern Himalayan Regions are the focused biodiversity hotspots of India. North-East (N.E) India is included the eight states encompassing Assam, Manipur, Arunachal Pradesh, Nagaland, Tripura, Meghalaya, Mizoram, and Sikkim and supports half of India's biodiversity. The region spreads more than $255,037 \mathrm{~km}^{2}$ or about $7.7 \%$ of India's aggregate geological territory. N.E sates mostly rocky with plateaus, slopes and mountains overwhelming. Level marshes are at a top-notch covering just $27 \%$ of the region. Rainfall is exuberant with $6,300 \mathrm{~mm}$ yearly a normal event in the Cherrapunji region. In the rest of the N.E region, normal yearly precipitation ranges from 1000 to more than $4000 \mathrm{~mm}$ with the affluent occurrence during the monsoon periods of June-October. Originating from this rich tropical vegetation ranging from alpine, subtropical pine and mountain to evergreen and wet deciduous flourishes making the region a focus of worldwide biodiversity hotspot [1,2]. N.E states of India is honored with an extensive variety of physiographic and ecoclimatic conditions and above all is the topographical passage for quite a bit of India's endemic flora.

- $\quad$ Of the nine vegetation types of India; six important types are well established in N.E region.

- Of about 15000 flowering plant species, 8000 are found in the N.E area, which includes 500 pteridophytes, 40 gymnosperms, 825 orchids, 25 species of canes, 80 species of rhododendrons, and 60 bamboo species.

- An aggregate of 3624 species of insects, 236 species of fishes, 137 species of reptiles, 50 molluscs, 64 amphibians, 160 mammalian species, and 850 birds have been so far revealed, and the count is continuously rising.

- $\quad$ Out of 15 known species belonging to three families of primates,' 9 found in N.E region.

- Of 6 largest cats from India and the globe; N.E region registers 4, especially the clouded leopards.
In addition, the region represents an essential part of the Indo-Myanmar biodiversity hotspot, among the 25 world's biodiversity hotspots recognized to date over the globe [3]. 51 unique forest are found in this region, which incorporates tropical moist deciduous forests, evergreen semi-tropical forests, and evergreen wet tropical forests, moderate and subtropical, and mountainous forests [4]. Further, Fig. 1, depicts the percentage distribution of forest in N.E region and Table 1 summarizes eight states of N.E region with total area, climatic condition, and diversities of plant species.

Numerous valuable medicinal plants are practically associated culturally as well as socially. In addition, these plants are generally utilized for food, clothing, fuel, shelter, and different necessities of sustainable life by the local inhabitants and indigenous communities of this region [5]. Among extensive diversity of medicinal plants, C. gynandra has been found abundantly growing as a weed in common infertile land and in crop grounds $[6,7]$.

\section{Cleome gynandra Linn.}

Cleome is a genus of the family Cleomaceae (formerly Capparaceae) is a major group of angiosperms, comprising many species found in tropical and sub-tropical areas of the globe. Cleomaceae family, encompassing flowering plants are Brassicales (or Cruciales) order, including more than 764 species belonging to 12 genera of which Cleome is the largest genus with about 601 species of ecological, ethnobotanical, and of course medicinal importance $[6,8,9]$. Different species of Cleome are therapeutically utilized in Island, North and Central America, Philippines, and Indo-China. In India, of 15 species 12 are reported in Maharashtra [10]. Cleome genus is under constant advancement; numerous species demonstrate a progressive movement from C3 photosynthesis to C4 photosynthesis and this developmental movement is indistinguishable to Brassicaceae individuals like Arabidopsis thaliana. There is extremely inadequate and scattered work in the genus, Cleome. Especially, the anatomical and physiological examinations in the species are uncommon [11]. C. gynandra is an 
Table 1: Area, climatic condition, plant diversity in North Eastern states of India

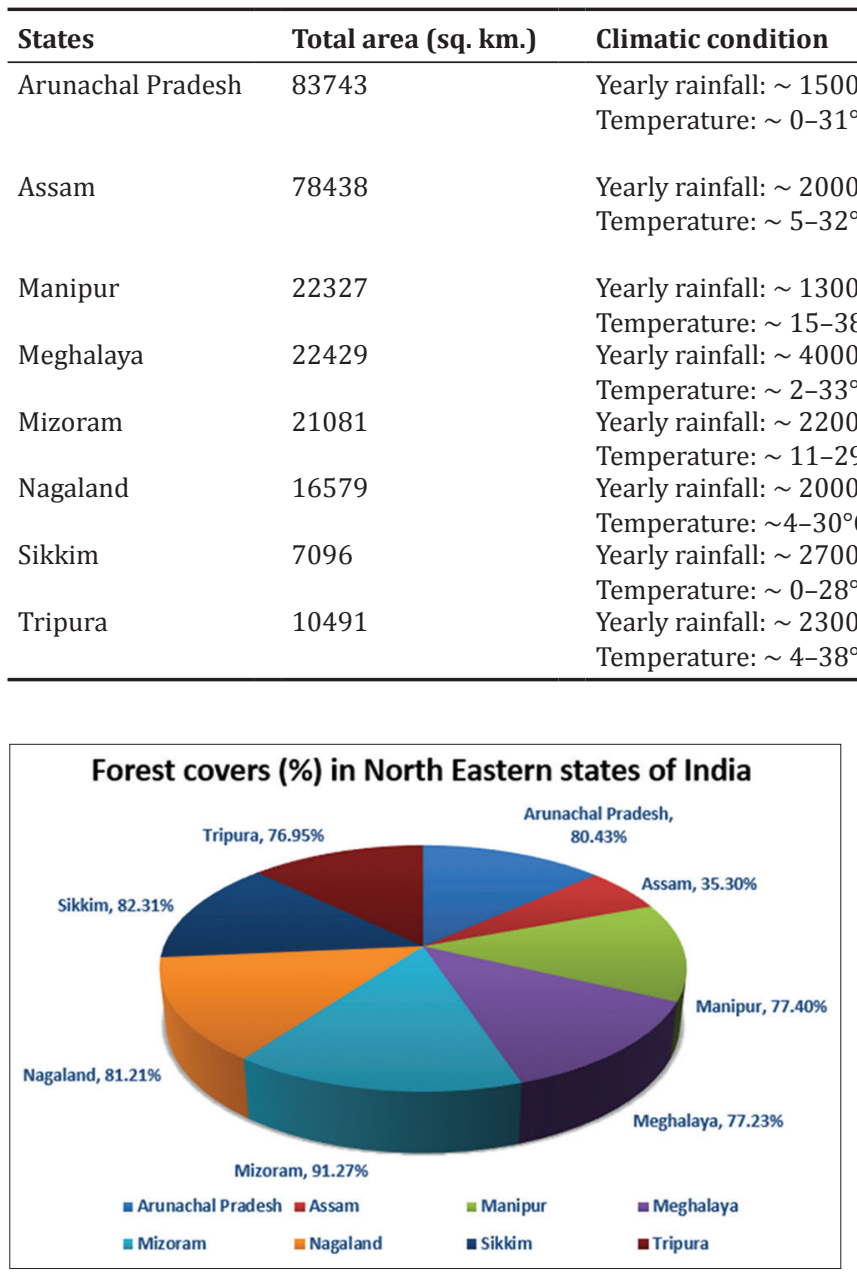

Fig. 1: The percentage distribution of forest in North-East region

opulently accessible species and matures as a weed in common sterile land and in crop grounds throughout the world. As a weed, it is generally found growing on fertile soils, particularly in those previously blended with animal fertilize, or with homestead disposed. Ideal growing conditions for C. gynandra require suitable soil moisture, high-intensity light and temperatures of $\sim 25^{\circ} \mathrm{C}$. In different countries, it is used to treat many diseases as traditional medicine, and it is additionally utilized as a part of different conventional culinary systems for it's astounding antioxidant and nutritional activities [12-14].

\section{Synonyms of Cleome gynandra L. [9]}

- Gynandropsis gynandra (L.) Briq.

- Gymnogonia pentaphylla (L.) R. Br. ex Steud.

- Gynandropsis pentaphylla Blanco.

- Cleome pentaphylla L.

- Cleome pentaphylla var. glabra Kuntze.

- Pedicellaria pentaphylla (L.) Schrank.

- Pedicellaria pentaphylla (L.) Schrank.

- Pedicellaria triphylla (L.) Pax.

- Gynandropsis pentaphylla (L.) DC.

- Podogyne pentaphylla (L.) Hoffmanns.

- Gynandropsis heterotricha DC.

- Gynandropsis glandulosa C. Presl.

- Cleome acuta Schumach. and Thonn.

Taxonomic position of Cleome gynandra $\mathrm{L}$. is as follows

- Kingdom: Plantae

- Division: Angiosperms
- Class: Dicotyledones

- Order: Capparidales (Capparales)

- Family: Cleomaceae

- Genus: Cleome

- Species: Gynandra.

\section{Plant distribution}

C. gynandra is typically well-known herb in southern Africa reaching out from the Limpopo, the North-West, Mpumalanga, Gauteng, the Northern Cape, and Namibia. Being semi-cultivated, in the District of Eastern Cape, has most likely broadened its distribution. It is most likely a native of Africa and now broadly circulated in tropical and subtropical areas all through the world $[6,15]$.

The species is also native to the following regions/countries [15]

- Northern Africa: Egypt and Mauritania

- Western Africa: Cameroon, Ghana, Guinea, Côte d'Ivoire, Mali, Niger, Nigeria, and Sierra Leone

- Central Africa: Angola, Burundi, and Zaire Eastern

- Africa: Ethiopia, Kenya, Somalia, Sudan, Tanzania, and Uganda

- African Islands: Madagascar, Mauritius, Reunion, and Seychelles

- Middle East: Oman and North Yemen

- Far East: Afghanistan

- Asia: Borneo, India, Java, Malaysia, Moluccas, Philippines, Sri Lanka, Sulawesi, and Thailand

- Australasia: Fiji.

Numerous species of the genus Cleome are discovered from India, but most normally available species are the $C$. chelidonii with blue flower and $C$. viscosa with a yellow flower. A careful scrutiny reveals that the species is available in Sri Lanka to India in whole Asia. A summarized finding is tabulate in Table 2 w.r.t the occurrence or distribution, habit, some morphological traits, and flowering period.

In Indian literature $C$. gynandra is distinguished by the accompanying vernacular names of the following:

Vernacular names in India [14]

Sanskrit: Pasugandhi, Ajagandha

Assamese: Bhutmulla

Bengali: Hurhuria, Shulte

English: Dog Mustard

Gujarat: Talvani, Dhelitalavan

Hindi: Hulhul, Hurhur, Kavalia

Kannada: Naram bele Soppu, Nayeetulasi

Kashmiri: Gandi Buti 
Malayalam: Atunari vela

Marathi: Tilvan, Bhatvan, Mabli, Tilavana, Tilvant

Oriya: Anasorisia, Anasorisa, Hulhulia

Punjabi: Bugra

Tamil: Nal valai, Nal velai

Telugu: Vaminta, Vayinta.

This review endorses in N.E region of India the same plant abundantly found in pink mutant variety, Fig. 2 further illustrates the white; Fig. 2(a) and the pink; Fig. 2(b) mutant verities, respectively.

\section{Phytochemical importance of $C$. gynandra}

Qualitative phytochemical screening of the powdered leaf revealed the presence of following class of compounds summarized in Table 3 [16].

Agood number of phytochemicals have been isolated from different parts of white mutant $C$. gynandra which confirms its current understanding of nutritional claims and pharmacological evidence, whereas a few compounds, namely, clenbuterol, stearin compound, bicyclohexyl derivatives, and (5Z,8Z)-3-hydroxypropyl dodeca-5,8-dienoate only been isolated from the pink mutant variety, only available in N.E states. Table 4 further summarizes the isolated phytochemicals from both the mutant varieties of $C$. gynandra with respective citations.

\section{Pharmacological importance of C. gynandra}

The pharmacological importance of $C$. gynandra is referred in Ayurveda; Gulma (tumor, irregularity, or diverticulosis), Krmiroga (worm infection), Asthila (Prostate enlargement), Kandu (pruritus), and Karnaroga (ear infections) $[27,28]$. The indigenous information

Table 2: Summarized review of the specie available in Sri Lanka to India to whole Asia

\begin{tabular}{ll}
\hline Specifications & The plant Cleome gynandra Linn. \\
\hline Native & Shri Lanka to India to whole Asia \\
Morphology & The erect plant is 250-600 mm tall \\
Soil type needed & Black mostly with waste place \\
Habitat & Annual herb \\
Leaves & Mostly 5 foliate pinnately compound; leaf \\
& stalk is 20-50 mm long with glandular \\
& hairs \\
Fruits & The fruits are in capsule form \\
Microscopic structures & Dark brown, oily; under microscope shows \\
& a number of fragments of epidermis; Leaf \\
& thickness ranges from 112 to $398 \mu \mathrm{m}$ \\
Inflorescence & Corymbose-racemes \\
Flower color & White \\
Androecium & 6 \\
Gynoecium & Gynandrophore 1 cm long \\
Capsule (Length) & $4-8 \mathrm{~cm}$ \\
Seed & Muricate, dark brown, globose $1.5 \mathrm{~mm}$ in \\
Flowering and fruiting & diameter \\
\hline
\end{tabular}

of numerous traditional medicine has been figured, reported, and eventually wind up noticeably with composed frameworks of the drug, for example, Ayurveda, Unani, Siddha, and other indigenous traditional system throughout the world [8]. The following are some therapeutic investigation reported by various researchers from India and from other nations as well [14-24, 29,30]:

- Sap from leaves utilized as pain relieving agent, especially in cerebral pain.

- Sap from pounded leaves is pressed into ears, nostrils, and eyes to treat epileptic fits and ear infection.

- A decoction or mixture of bubbled leaves and/or roots is regulated to:

- Encourage labor pain in pregnant ladies.

- Treat stomach-throb and constipation.

- Treat conjunctivitis.

- Treat serious thread worm disease.

- Relieve burning chest pains.

- The leaves have anti-inflamatory activities and are utilized to treat joint inflammation.

- Leaves are rubefacient and vesicant and used to treat neuralgia, otalgia, rheumatism, and stiffness. The leaves are rubbed on the affected parts.

- In Taiwan, it is utilized to treat looseness of the bowels, gonorrhea, fever, and rheumatoid arthritis. In India, the plant has been usually utilized as a rubefacient and anthelmintic agents. Leaves are applied directly over the injuries to prevent sepsis. The plant also used to treat piles, different stomach aches and in tumor. The juice of the root is utilized to treat fevers.

- Bruised leaves are applied to boils to stop pus discharge.

- Infusion from leaves is utilized to treat iron deficiency.

- Sap from the leaves used to cure intermittent intestinal sickness.

- Leaves are rubbed onto the skin to relieve pneumonia.

- An infusion of the leaves utilized as an eyewash.
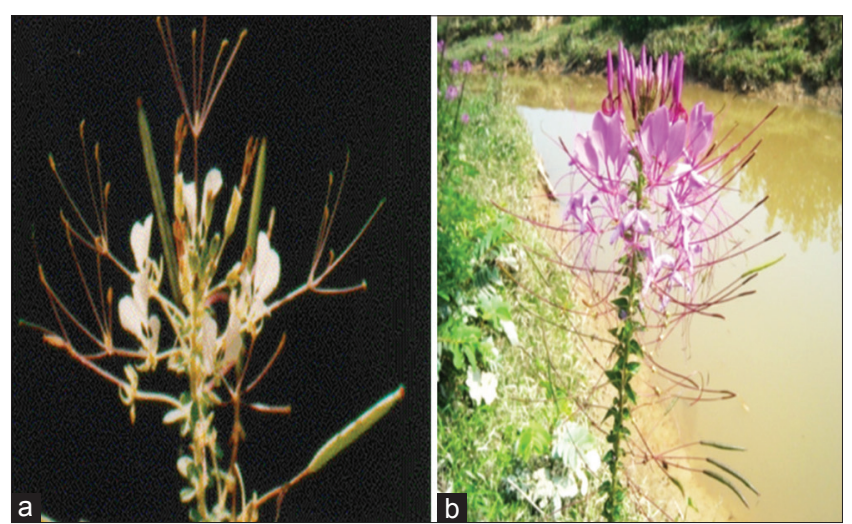

Fig. 2: Two mutant variety of Cleome gynandra. (a) White mutan C. gynandra in India, Sri Lanka to whole Asia. Source: [12] and http://www.ku.ac.th/AgrInfo/plant/plant2/p029.html. (b) Pink mutant $C$. gynandra only in North-East region. Source: [6]

Table 3: Qualitative phytochemical screening of the powdered leaf of $C$. gynandra

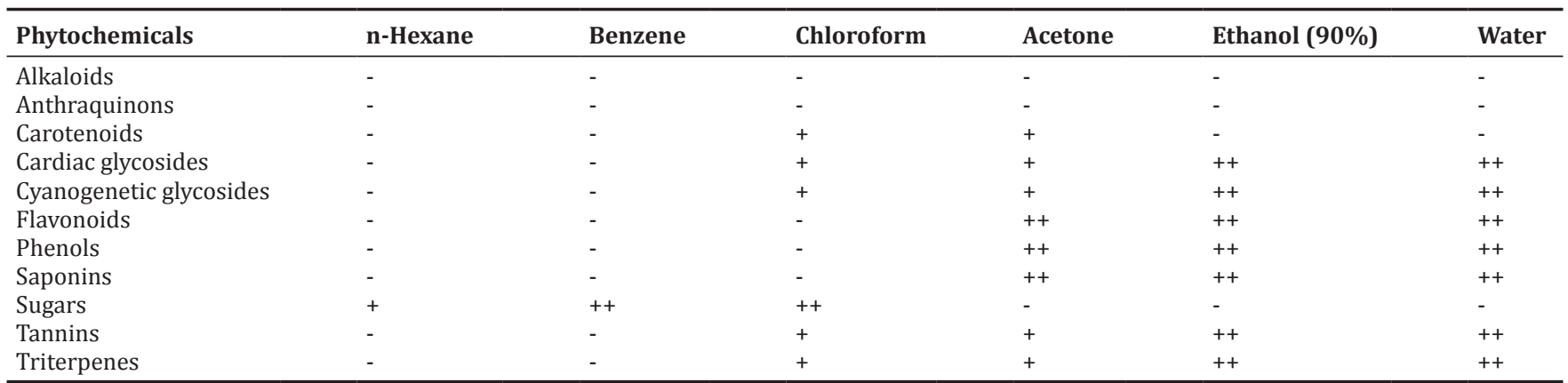

++: Marked change,+: Moderate change, -: No characteristic change 
Table 4: Brief review of the isolated phytochemicals from two mutant varieties of $C$. gynandra $[6,16]$

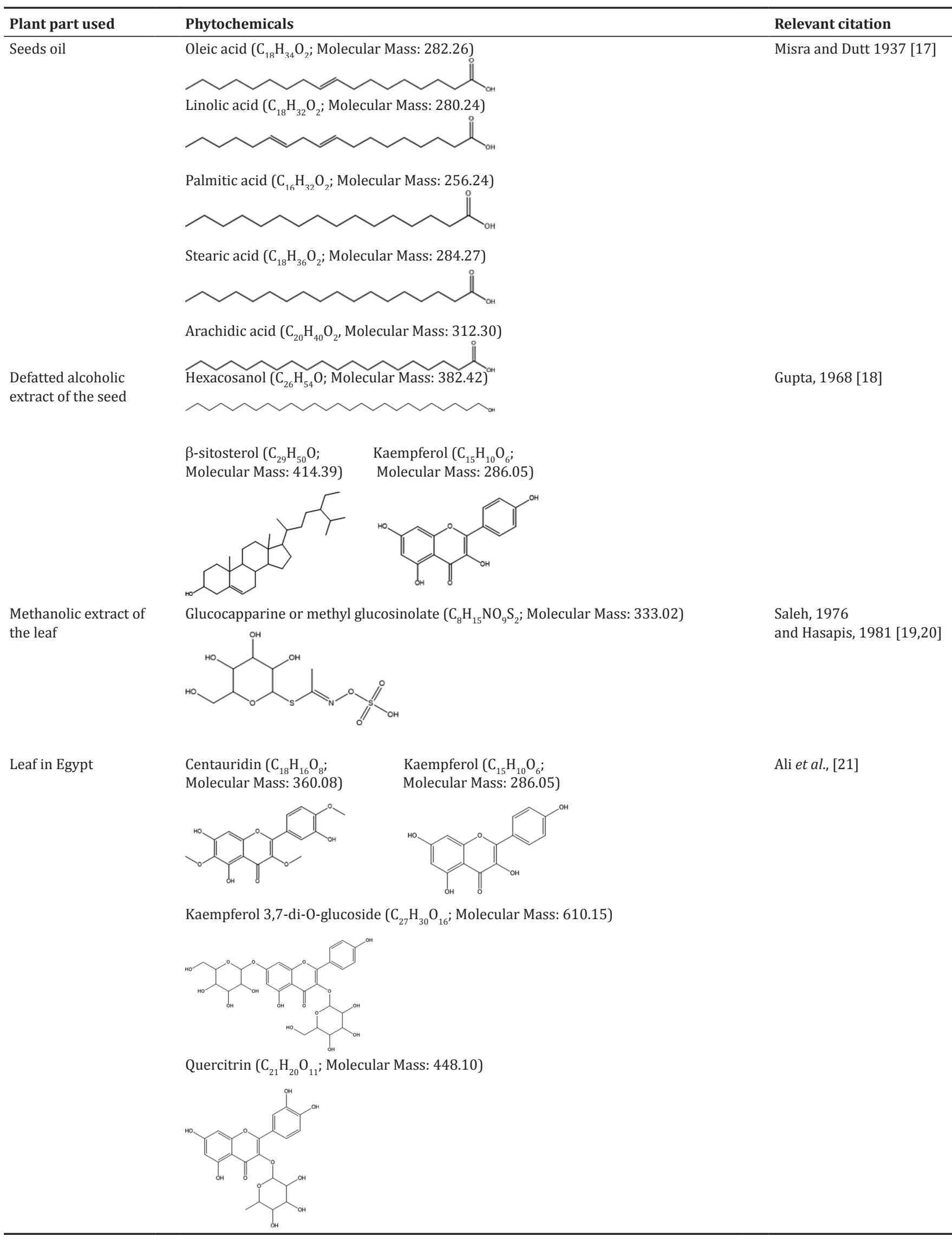


Table 4: (Continued)

Plant part used

Plant part used

Methanolic extract of the defatted seeds

Alcoholic extract fresh flower

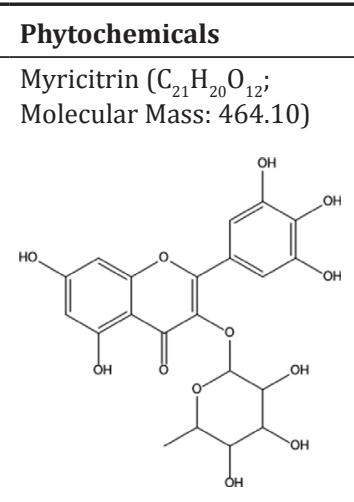

$\alpha$-amyrin $\left(\mathrm{C}_{30} \mathrm{H}_{50} \mathrm{O}\right.$

Molecular Mass: 426.39]

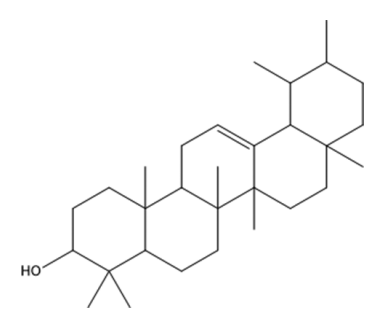

Relevant citation

$\beta$-amyrin $\left(\mathrm{C}_{30} \mathrm{H}_{50} \mathrm{O}\right.$

Molecular Mass: 426.39)

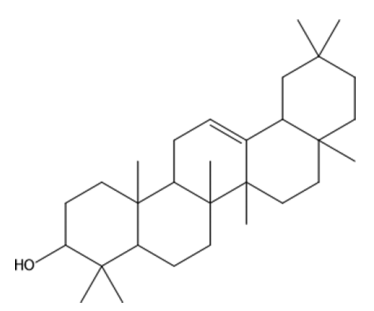

Taraxasterol $\left(\mathrm{C}_{30} \mathrm{H}_{50} \mathrm{O}\right.$

Molecular Mass: 426.39)

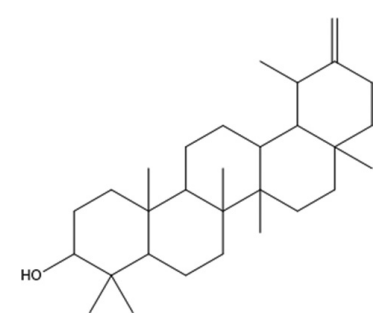

$\beta$-sitosterol $\left(\mathrm{C}_{29} \mathrm{H}_{50} \mathrm{O}\right.$; Molecular Mass: 414.39)<smiles>CCC(CCC(C)C1CCC2C3CC=C4CC(O)CCC4(C)C3CCC12C)C(C)C</smiles>

(Also isolated by Gupta, 1968)

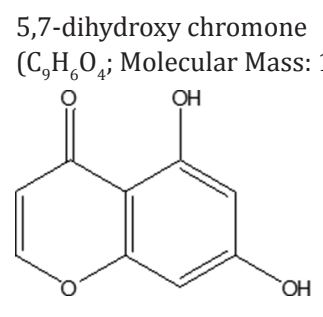

Luteolin $\left(\mathrm{C}_{15} \mathrm{H}_{10} \mathrm{O}_{6}\right.$;

Molecular Mass: 286.05)<smiles>O=c1cc(-c2ccc(O)c(O)c2)oc2cc(O)cc(O)c12</smiles>

Jain and Gupta; Rastogi et al. $[22,23]$

5-hydroxy -3,7,4/-trimethoxy flavones $\left(\mathrm{C}_{18} \mathrm{H}_{16} \mathrm{O}_{6}\right.$; Molecular Mass: 328.09)<smiles>COc1ccc(-c2oc3cc(OC)cc(Cl)c3c(=O)c2OC)cc1</smiles>

Rutin $\left(\mathrm{C}_{27} \mathrm{H}_{30} \mathrm{O}_{16}\right.$; Molecular Mass: 610.15) 
Table 4: (Continued)

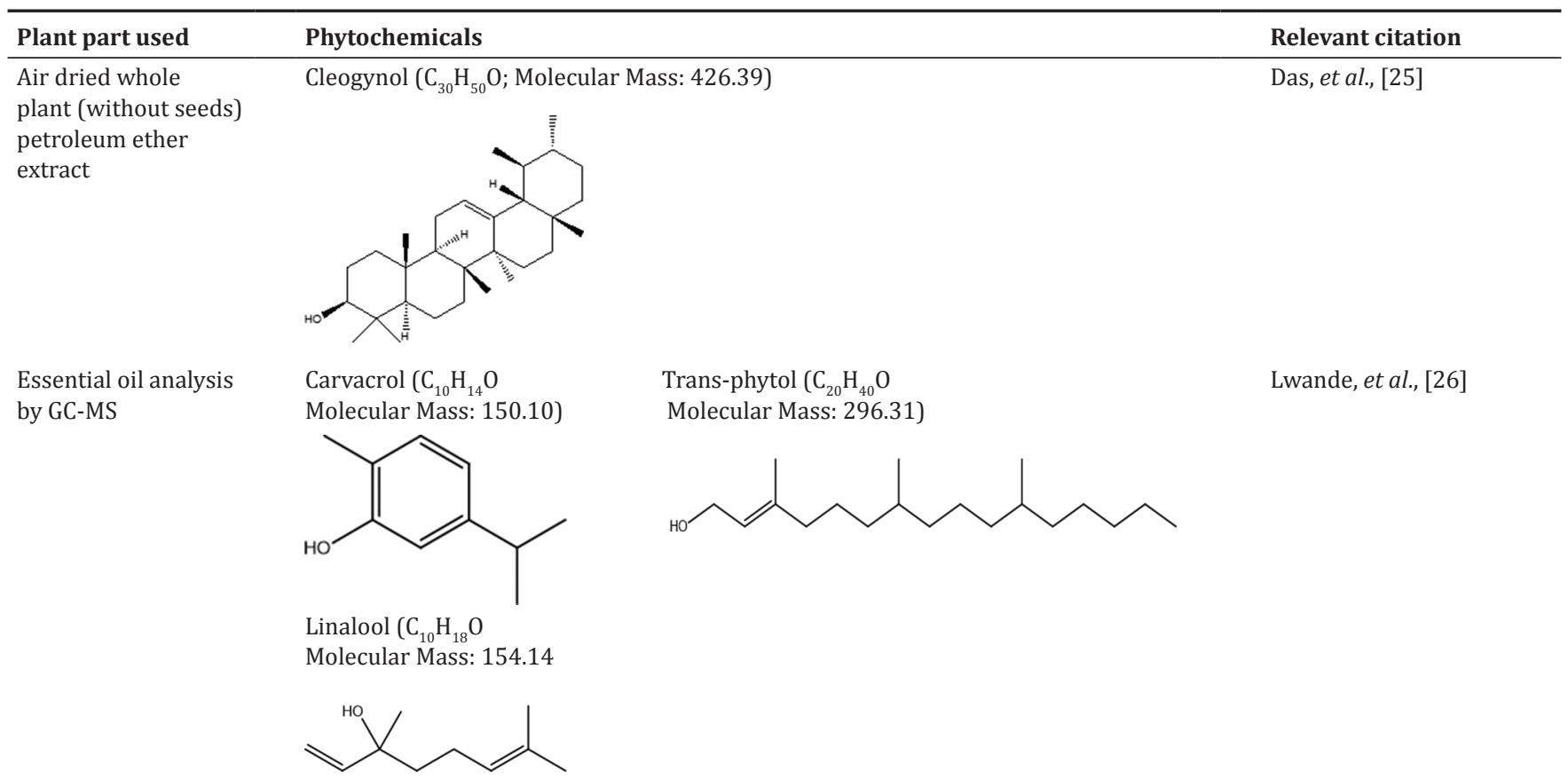

Trans-2-methyl cyclopentanol $\left(\mathrm{C}_{6} \mathrm{H}_{12} \mathrm{O}\right.$; Molecular Mass: 100.09)

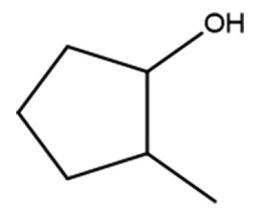

$\beta$-caryophyllene $\left(\mathrm{C}_{15} \mathrm{H}_{24}\right.$; Methyl isocyanate $\left(\mathrm{C}_{2} \mathrm{H}_{3} \mathrm{NO}\right.$; Molecular Mass: 204.19) Molecular Mass: 57.02)
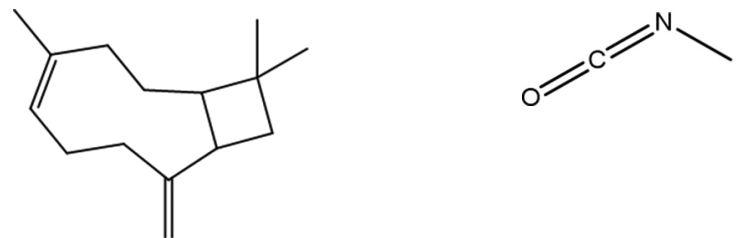

Argentation-TLC followed by

re-crystallization of fractions of seed oil

Clenbuterol $\left(\mathrm{C}_{60} \mathrm{H}_{98} \mathrm{O}_{2}\right.$; Molecular Mass: 850.76)

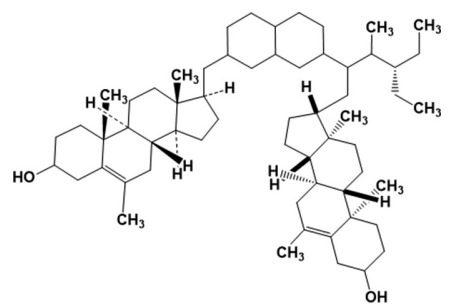

$\beta$-sitosterol $\left(\mathrm{C}_{29} \mathrm{H}_{50} \mathrm{O}\right.$; Molecular Mass: 414.39)

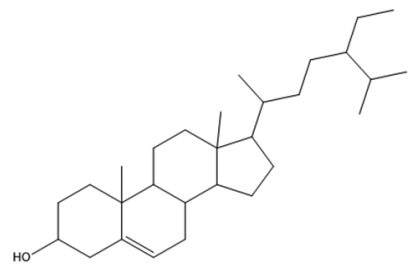

Roy, S,

Ph.D Thesis

2007 [27] 
Table 4: (Continued)

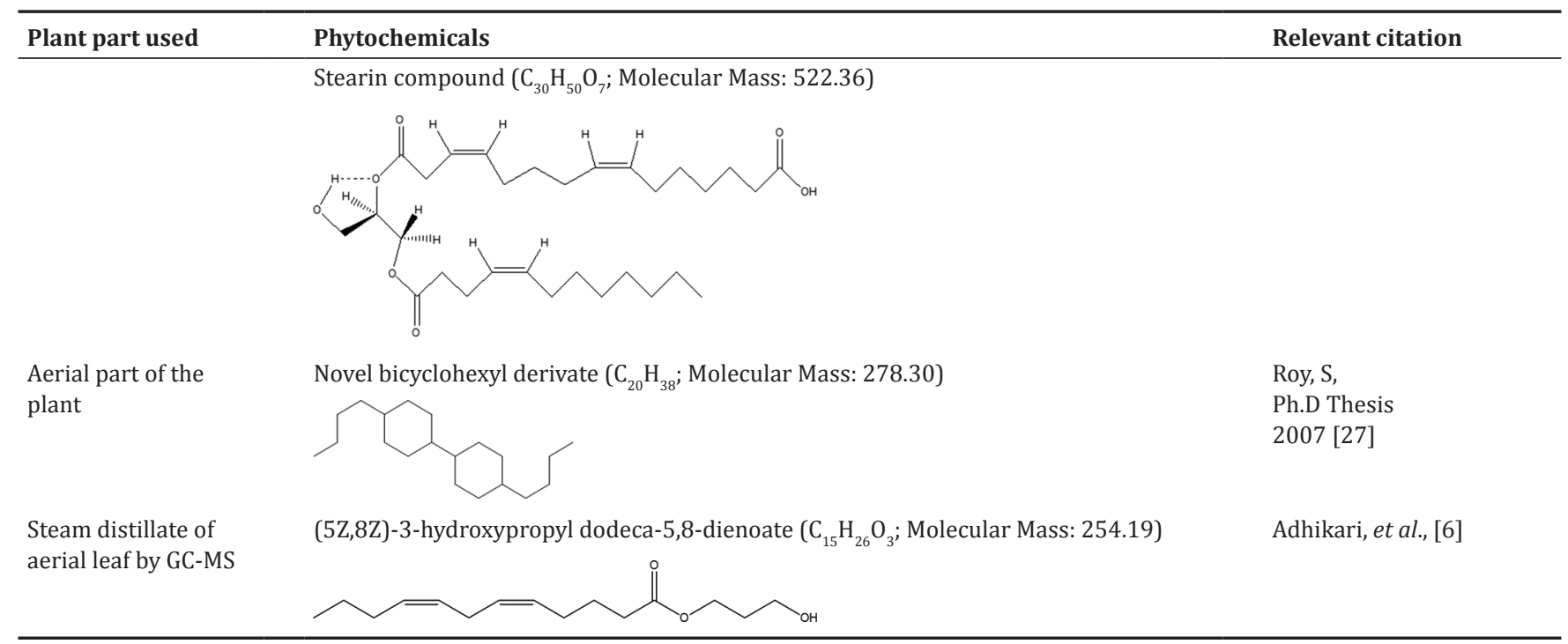

TLC: Thin-layer chromatography, GC-MS: Gas chromatography-mass spectrometry

- Seeds are anthelmintic and rubefacient and are consumed for the removal of roundworms, or a mixture is applied externally on the stomach as a painkiller.

- $\quad$ Seeds are blended with oil and applied to the scalp to treat headache.

- Mixture of seed controls coughing.

- Seeds are also utilized for veterinarians to treat stomach pains.

- Leaves and the plant have anti-ticks and fleas preventive properties.

- A decoction of roots is accounted for to have gentle febrifugal properties

- Anthelmintic properties own by roots.

\section{As an anti-inflammatory agent}

In 2008 group of scientists uncovered the anti-inflammatory action of $C$. gynandra. They utilized thermal stimuli in hotplate test and the writhing reaction of the tested animals to an intraperitoneal infusion. From the outcomes, it was clear that the aqueous extract, to an intraperitoneal infusion. From the outcomes, it was clear that a notable antinociceptive activity in the hotplate test and writhing response, which is similar to that of the standard. Studies show that different flavonoids, for example, luteolin, rutin, hesperidin, quercetin, and bioflavonoids produced substantial antinociceptive and anti-inflammatory activities [31]. A couple of reports on tannins as anti-inflammatory activities and antinociceptive properties. NSAIDs; nonsteroidal antiinflammatory drugs in peripheral tissues can hinder cyclooxygenase, thus interfere transduction mechanism. The antinociceptive activity could be because of the flavonoid-mediated peripheral mechanism. Most of the NSAIDs have all around adjusted mitigating and ulcerogenic exercises, which are thought to be because of prostaglandins synthetase inhibitor activity [32-34].

\section{As a free radical scavenging agent}

The generation of free radicals has been concerned in the causation of a few sicknesses of referred to an obscure etiologies, for example, diabetes, cancer, rheumatoid arthritis, and so forth., and especially phytochemicals that can scavenge free radicals have extraordinary potential in protecting these ailments. The research trials on animal models showed an excellent radical scavenging capacity of $C$. gynandra alcoholic leaf extract on experimental rats at a dose of $150 \mathrm{mg} / \mathrm{kg}$ for a 30 days trial in induced arthritis rats. Furthermore, the leaf extract increased lipid peroxidase levels significantly. Glutathione peroxidase activities; reduced glutathione and superoxide dismutase activity were also decreased significantly. The free radical scavenging capacity of $C$. gynandra leaf extract was additionally confirm by histological examination $[16,32,35]$.

\section{As an anticancerous agent}

Anticancer activity of methanolic extract of $C$. gynandra was assessed against Ehrlich Ascites Carcinoma cell line at the doses of 400 and $200 \mathrm{mg} / \mathrm{kg}$ body weight intraperitoneally. The outcome indicated significant decline in tumor volume, viable cell count, tumor weight, and raised the life expectancy of tumor-bearing mice when compared with normal control mice. Hemoglobin, red blood cell, white blood cell, and lymphocyte count returned to the normal level in treated mice. Result reveals the extract has potent dose-dependent anticancer activity [36].

\section{As an Immunomodulator}

Aqueous and alcoholic extracts of C. gynandra significantly diminishes the level of serum immunoglobulin $G(\operatorname{IgG})$ in correlations with the level of IgG. Both aqueous and alcoholic extracts separately influenced IgM and IgG levels. Among the two tested samples, alcoholic extract demonstrated better activity even with lower amounts. The general pharmacological examinations strongly show the immunosuppressant activity of the alcoholic extracts and the aqueous extract of $C$. gynandra. Therefore, $\mathrm{T}$ cell-dependent antigen shown the inhibitory effect of both the extracts on $\mathrm{T}$ cells. The ethanolic extract of $C$. gynandra demonstrations better action; inhibition about $92.74 \%$ cell-induced hypersensitivity in the albino rat to evaluate the impact of the division on cell-mediated immunity [12].

\section{As an antidiabetic agent}

Herbal formulation of plants containing minor and trace elements in bioavailable that positively impacts glucose resistance and potentially increases self-ability to improve the diabetic condition. Essential nutrients such as $\mathrm{Mg}, \mathrm{Na}, \mathrm{Fe}, \mathrm{Ca}, \mathrm{Se}, \mathrm{Cu}$, and $\mathrm{Zn}$ has confirmed that many Indian herbs like Eugenia jambolana responsible for curing diabetes by providing fundamental supplements [37].

In some place of western Orissa, the leaves and roots are utilized by tribal people and conventional healers as an antidiabetic medicine. The reason of C. gynandra to use in diabetes might be anticipated for its antioxidant activities, its nutritive capacity, and immunomodulatory properties. The glucose oxidation enhancing pathway, because of the dynamic phytochemicals are probably to be its polyphenolic compounds. A diabetic inconvenience like diabetic nephropathy (DN) is a serious and life-threatening complexity of chronic diabetes. As one of the primary factor of renal disorder, the prevention and treatment of DN in its beginning phase, and the decrease of DN advancement are of most extreme significance and are emerging subjects current research. Natural products enriched with antioxidant 
and anti-inflammatory capacities may offer a chance of synergistic treatment for this situation. The various plant phytocompounds supplementation does not have any huge effect on plasma glucose but rather altogether found to diminish malondialdehyde plasma level and the general redox parameters together with a fractional moderation of proteinuria. The experimental results demonstrate that, other than the control of glycemia, interference of phytochemicals with antioxidant and anti-inflammatory properties may have advantageous impacts when coordinated in the standard of the therapeutic regimen. Polyphenolic constituents and flavones' intervention of $C$. gynandra have been appeared to be in response for the antioxidant property and have been attributed to different properties such as anticancer, antidiabetic, and inhibition of cardiovascular diseases. The aqueous and alcoholic extracts of $C$. gynandra are a possible foundation of natural antioxidants such as polyphenols and flavonoids. This can be utilized for an effective antioxidant compound that can shield from oxidative. Until April 2014 no hypoglycemic properties were considered or demonstrated. Ravichandra et al., 2014, concentrated the antidiabetic and antilipidemic properties of C. gynandra in alloxaninduced diabetic rats. Ravichandra et al. concentrated the antidiabetic a hostile to dyslipidemic movement of $C$. gynandra plant extricates in alloxan incited diabetic rats. The effect on the oral administration of alcoholic extract significantly reduced serum glucose and lipid profiles in diabetic control when compared with normal groups. Examination recommended that alcoholic extract of C. gynandra restrains blood glucose levels and dyslipidemia in diabetes rats. Therefore, leaf decoction of $C$. gynandra folk claims has been ascertained. Further, the mechanism of lowering blood sugar may be attributed to the presence of micronutrients and polyphenolics [10].

\section{CONCLUSION}

Over the past two decades, an expanding body of evidence from epidemiological and laboratory studies of the plant C. gynandra L. have demonstrated some nutritional aspect and identified ingredients with potent therapeutic values. Scientific perusal reveals $C$. gynandra has an excellent an indigenous medicine and act as an inflammatory, radical scavenging, anticancerous, immunomodulatory, and antidiabetics agent. Furthermore, C. gynandra has been used as several other ailments.

Yet, research needs to focus on the isolation of nutritional and therapeutic principles of $C$. gynandra. Survey of literature motivates both Re-search and Research of the plant to add new empirical solutions of many life-threatening diseases. Evaluation of synergistic/antagonistic outcome may include new herbal medicines to health-care management systems. Because most of the reports in India on this plant that has been carried out on the white mutant variety. However, in North-Eastern region the same plant abundantly found only in pink mutant variety. Extensive research needs to scrutiny this diversity of the plant in this biodiverse region.

\section{ACKNOWLEDGMENTS}

PPA is thankful to University Grants Commission, New Delhi for financial assistance through a UGC-MRP (F. 36-260/2008) to SBP

\section{REFERENCES}

1. Sharma M, Sharma CL. Indigenous uses of medicinal plants in North Garo Hills, Meghalaya, NE India. Res J Recent Sci 2014;3:137-46.

2. Bhattacharyya PN, Tanti B, Barman P, Jha DK. Culture-independent metagenomic approach to characterize the surface and subsurface soil bacterial community in the Brahmaputra valley, Assam, North-East India, an Indo-Burma mega-biodiversity hotspot. World J Microbiol Biotechnol 2014;30:519-28.

3. Sahu J, Sen P, Choudhury MD, Dehury B, Barooah M, Modi MK, et al. Rediscovering medicinal plants' potential with OMICS: Microsatellite survey in expressed sequence tags of eleven traditional plants with potent antidiabetic properties. OMICS 2014;18:298-309.
4. Chakraborty R, De B, Devanna N, Sen S. North-East India an ethnic storehouse of unexplored medicinal plants. J Nat Prod Plant Resour 2012;2:143-52.

5. Adhikari PP, Talukdar S, Borah A. Ethnomedicobotanical study of indigenous knowledge on medicinal plants used for the treatment of reproductive problems in Nalbari district, Assam, India. J Ethnopharmacol 2017;210:386-407.

6. Adhikari PP, Paul SB, Choudhury MD, Choudhury S. GC-MS studies on the steam-distillate of the medicinally important plant Cleome gynandra L. Int J Appl Res Stud 2014;3:1-4.

7. Aparadh VT, Mahamuni RJ, Karadge BA. Taxonomy and physiological studies in spider flower (Cleome species): A critical review. Plant Sci Feed 2012;2:25-46.

8. The Plant List. The Plant List, Version 1; 2010. Available from: http:// www.theplantlist.org. [Last cited on Jan 01] [Last accessed on Aug 15].

9. Ravichandra B, Ram PS, Saritha C, Shankaraiah P. Anti-diabetic and anti-dyslipidemia activities of Cleome gynandra in alloxan induced diabetic rats. J Pharm Toxicol 2014;9:55-61.

10. Marshall DM, Muhaidat R, Brown NJ, Liu Z, Stanley S, Griffiths H, et al. Cleome, a genus closely related to Arabidopsis, contains species spanning a developmental progression from $\mathrm{C}(3)$ to $\mathrm{C}(4)$ photosynthesis. Plant J 2007;51:886-96.

11. Kori ML, Gaur K, Dixit VK. Investigation of immunomodulatory potential of Cleome gynandra Linn. Asian J Pharm Clin Res 2009:2:35-9

12. Albarello N, Simões C, Rosas PF, Castro TC, Gianfaldoni MG, Callado CH, et al. In vitro propagation of Cleome spinosa (Capparaceae) using explants from nursery-grown seedlings and axenic plants. Vitro Cell Dev Biol Plant 2006;42:601-6.

13. Mishra SS, Moharana SK, Dash MR. Review on Cleome gynandra. Int J Res Pharm Chem 2011;1:681-9.

14. Chweya JA, Mnzava NA. Cat's Whiskers, Cleome gynandra L. Vol. 11. Rome, Italy: Bioversity International; 1997.

15. Anbazhagi T, Kadavul K, Suguna G, Petrus AJ. Studies on pharmacognostical and in vitro antioxidant potential of Cleome gynandra Linn. leaves. Nat Prod Radian 2009;8:151-7.

16. Paul SB, Choudhury S, Adhikari PP. Isolated chemical components from spider weed, Cleome gynandra Linn: An overview. Assam Univ J Sci Technol 2012;10:166-73.

17. Misra RN, Dutt S. Chemical examination of cleoaie Pentaphylla Linn. Part Ii. oonstituents of the oil from. The seeds. Proc Natl Inst Sci India 1937;3:45.

18. Gupta RK, Chandra S, Mahadevan B. Chemical examination of seeds of Gynandropsis pentaphylla. Indian J Pharm 1968;30:127.

19. Saleh M. Phytochemical and botanical study of Gynandropsis sp. Part-I. Gynandropsis glucosinolates. Pharmazie 1976;31:818

20. Hasapis X, MacLeod AJ, Moreau M. Glucosinolates of nine cruciferae and two Capparaceae species. Phytochemistry 1981;20:2355-8.

21. Ali AA, Sayed HM, Mesbah MK. Pharmacognosical study of Gynandropsis pentaphylla growing in Egypt, Pt. III. Bull Pharm Sci Assiut Univ 1987;10:74.

22. Jain AC, Gupta SM. Minor phenolic components of the seeds of Gynandropsis gynandra. J Nat Prod 1985;48:332-3.

23. Rastogi RP, Mehrotra BN. Cleome gynandra, Compendium of Indian Medicinal Plants. Vol. II, III, IV. New Delhi: CSIR; 1993. p. 112, 182, 193, 198.

24. Ragunathan V, Jaswant V, Sulochana N. Rutin from flowers of Cleome gyanandra Linn. J Ind Chem Soc 1997;74:821.

25. Das PC, Patra A, Mandal S, Mallick B, Das A, Chatterjee A. Cleogynol, a novel dammarane triterpenoid from Cleome gynandra. J Nat Prod 1999;62:616-8.

26. Lwande W, Ndakala A, Hassanali A, Moreka L, Nyandat E, Ndungu M, et al. Gynandropsis gynandra essential oil and its constituents as tick (Rhipicephalus appendiculatus) repellents. Phytochemistry 1999;50:401-5.

27. Roy S. Chemical and Biological studies on Cleome gynandra L. PhD Thesis. Silchar, India: Assam University; 2007. p. 2-23.

28. Ayurvedic Pharmacopoeia of India, Part I. Government of India, Ministry of Health and Family Welfare. Vol. I. New Delhi, India: Department of Indian Systems of Medicine and Homoeopathy; 2001.

29. Ayurvedic Pharmacopoeia of India. Part I, Government of India, Ministry of Health and Family Welfare. Vol. II. New Delhi, India: Department of Indian Systems of Medicine and Homoeopathy; 2001a.

30. Mule SN, Ghadge RV, Chopade AR, Bagul BA, Patil SB, Naikwade NS. Evaluation of anti-nociceptive and anti-inflammatory activity of leaves of Gynandropsis pentaphylla. J Herbal Med Toxicol 2008;2:41-4

31. Narendhirakannan RT, Kandaswamy M, Subramanian S. 
Anti-inflammatory activity of Cleome gynandra L. on hematological and cellular constituents in adjuvant-induced arthritic rats. J Med Food 2005;8:93-9.

32. Narendhirakannan RT, Subramanian S, Kandaswamy M. Free radical scavenging activity of Cleome gynandra L. leaves on adjuvant induced arthritis in rats. Mol Cell Biochem 2005;276:71-80.

33. Bala A, Kar B, Haldar PK, Mazumder UK, Bera S. Evaluation of anticancer activity of Cleome gynandra on ehrlich's ascites carcinoma treated mice. J Ethnopharmacol 2010;129:131-4.

34. Knekt P, Kumpulainen J, Järvinen R, Rissanen H, Heliövaara M,
Reunanen A, et al. Flavonoid intake and risk of chronic diseases. Am J Clin Nutr 2002;76:560-8.

35. Arora S, Kumar G, Meena S. Gas chromatography-mass spectroscopy analysis of root of an economically important plant, Cenchrus ciliaris L. from thar desert, Rajasthan (India). Asian J Pharm Clin Res 2017;10:64.

36. Nagpal M, Aggarwal G, Jain UK, Madan J. Extraction of gum from Abelmoschus esculentus: Physicochemical peculiarity and antioxidant prepatent. Asian J Pharm Clin Res 2017;10:174.

37. Das A, Ahmed AB. Natural permeation enhancer for transdermal drug delivery system and permeation evaluation: A review. Asian J Pharm Clin Res 2017;10:5. 